\title{
CHLOROPHYLL CONTENT OF THE HOPE MUTANT CLONES OF BOGOR TARO (Colocasia esculenta (L.) Schott)
}

\author{
Hilda Izzatul Adibah, Febi Nurilmala*, dan Ade Ayu Oksari \\ Program Studi Biologi, Fakultas MIPA, Universitas Nusa Bangsa Bogor \\ Jl. K.H. Sholeh Iskandar Km. 4 Cimanggu Tanah Sareal, Bogor 16166
}

\section{ARTICLE INFO}

Article history:

Received 28 Jan 2021,

Accepted 13 Apr 2021

Available online 29 Apr 2021

Keywords:

$\checkmark$ Chlorophyll a

$\checkmark$ Chlorophyll b

$\checkmark$ Fotosyntesis

$\checkmark$ Mutant clone

$\checkmark$ Colocasia esculenta

*corresponding author: febinuril@gmail.com

Phone: +62 ;

https://doi.org/10.31938/jsn.v $11 \mathrm{i} 1.293$

\section{ABSTRACT}

The development of the Bogor taro plant genetic variation with gamma-ray radiation has resulted in three mutant clones of the hope line with high carbohydrate and low calcium oxalate advantages. The carbohydrate content may correlate with chlorophyll content which plays a role in the photosynthesis process, so it is necessary to know the chlorophyll content in the mutant clones of the Bogor taro hope line and its relationship with its growth in two locations in Kemang District and Cijeruk District, Bogor Regency. The results showed that the mutant clones of the hope line B1023 planted in Kemang District had higher chlorophyll content than the parents. Meanwhile, the mutant clones of the hope line B1511 planted in the Cijeruk District had higher chlorophyll content than the parents. The chlorophyll content of the hope mutant clones planted in Kemang District was higher than the hope mutant clones planted in Cijeruk District. High chlorophyll content showed a negative relationship with tuber wet weight and carbohydrate content but did not affect the number of leaves and tillers

\section{ABSTRAK \\ Kandungan klorofil dan pertumbuhan pada klon mutan galur harapan tanaman talas Bogor (Colocasia esculenta (L.) Schott)}

Pengembangan variasi genetik tanaman talas Bogor dengan radiasi sinar gamma telah menghasilkan tiga klon mutan galur harapan dengan keunggulan tinggi karbohidrat dan rendah kalsium oksalat. Kandungan karbohidrat mungkin berhubungan erat dengan kandungan klorofil yang berperan dalam proses fotosintesis, sehingga perlu untuk diketahui kandungan klorofil pada klon mutan galur harapan tanaman talas Bogor dan hubungannya dengan pertumbuhannya di dua lokasi Kecamatan Kemang dan Kecamatan Cijeruk Kabupaten Bogor. Hasil penelitian menunjukkan bahwa klon mutan galur harapan B1023 yang ditanam di Kecamatan Kemang memiliki kandungan klorofil lebih tinggi dari tetua. Sedangkan pada klon mutan galur harapan B1511 yang ditanam di Kecamatan Cijeruk memiliki kandungan klorofil lebih tinggi dari tetua. Kandungan klorofil klon mutan galur harapan yang ditanam di Kecamatan Kemang lebih tinggi dibandingkan dengan kandungan klorofil klon mutan harapan yang ditanam di Kecamatan Cijeruk. Kandungan klorofil tinggi menunjukkan hubungan negatif dengan bobot basah umbi dan kandungan karbohidrat, tetapi tidak memberikan pengaruh terhadap jumlah daun dan anakan.

Kata kunci: Klorofil a, Klorofil b, Fotosintesis, Klon mutan, Colocasia esculenta 


\section{PENDAHULUAN}

Tanaman talas (Colocasia esculenta (L.) Schott) merupakan tanaman pangan lokal yang berpotensi untuk dikembangkan dalam program penganekaragaman pangan sebagai pilihan sumber karbohidrat. Perbanyakan tanaman talas selama ini dilakukan secara vegetatif sehingga keragaman genetiknya menjadi sempit. Untuk memperluas keragaman genetik tanaman talas dapat diupayakan beberapa strategi dengan fusi protoplas, mutasi atau teknik induksi poliploid (Wulansari, Marthin, Ermayanti, \& Muji, 2016). Induksi mutasi merupakan salah satu metode yang digunakan dalam kegiatan pemuliaan tanaman untuk memperluas plasma nutfah yang telah ada dan efektif untuk perbaikan varietas. Keunggulan metode ini adalah dapat memperbaiki suatu sifat menjadi sifat baru yang tidak dimiliki oleh induknya tanpa merubah sifat yang telah ada (Shu, Forster, \& H. Nakagawa, 2012). Mutasi dapat diinduksi secara fisik dengan menggunakan radiasi sinar gamma yang telah memberikan kontribusi nyata terhadap perbaikan tanaman (Bermawie, Meilawati, S. Purwiyant, \& Melati, 2015).

Pengembangan variasi genetik tanaman talas Bogor telah dilakukan dengan teknik mutasi melalui induksi variasi somaklonal menggunakan radiasi sinar gamma $\left(\mathrm{Co}^{60}\right)$ dosis $5,10,15$, dan 20 Gy (Nurilmala, Hutagaol, Widhyastini, Widyastuti, \& Suharsono, 2017). Setelah proses aklimatisasi didapatkan tiga klon mutan galur harapan yang memiliki keunggulan tinggi karbohidrat dan rendah kalsium oksalat dibandingkan dengan tetuanya (Nurilmala \& Mardiana, 2019). Selanjutnya dilakukan uji multilokasi di dua lokasi yaitu Kecamatan Kemang dan Kecamatan Cijeruk untuk mengetahui daya adaptasi dan kestabilan gennya. Tingginya kandungan karbohidrat pada klon mutan galur harapan diduga berhubungan dengan kandungan klorofil yang berperan dalam proses fotosintesis.

Klorofil daun yang terdiri atas klorofil $a, b$, maupun klorofil total mempengaruhi proses fotosintesis (Li, Guo, Baum, Grando, \& Ceccarelli, 2006), sedangkan pembentukan klorofil daun tersebut dipengaruhi oleh faktor genetik, sehingga apabila terjadi perubahan susunan genetik pada sel tanaman akan mempengaruhi jumlah klorofil daunnya (Mugiono, 1996). Salah satu parameter penting untuk mengevaluasi terjadinya mutasi akibat radiasi Sinar Gamma adalah mutasi klorofil (FAO/IAEA DIVISIONOF ATOMIC ENERGY IN FOOD AND AGRICULTURE, 1977). Oleh karena itu, besarnya kandungan klorofil dalam tanaman dapat mempengaruhi kemampuan tanaman mengabsorbsi cahaya dan berdampak pula pada hasil fotosintat yaitu karbohidrat (Suminarti, 2010) yang akan mempengaruhi pertumbuhan tanaman. Dengan demikian, tujuan penelitian yang dilakukan adalah untuk mengetahui kandungan klorofil pada klon mutan galur harapan tanaman talas Bogor dan hubungannya dengan pertumbuhannya di dua lokasi Kecamatan Kemang dan Kecamatan Cijeruk Kabupaten Bogor.

\section{BAHAN DAN METODE}

\section{Bahan dan Alat}

Bahan-bahan yang digunakan adalah tanaman talas tetua dan tiga klon mutan galur harapan (B521, B1023, dan B1511) koleksi Universitas Nusa Bangsa Bogor, daun serta umbi talas tetua dan klon mutan galur harapan yang dipanen di Kecamatan Kemang dan Kecamatan Cijeruk, aseton Smart-Lab 99.50\% (p.a), alkohol Smart-Lab 99,70\% (p.a), pereaksi Anthrone Merck, $\mathrm{CaCO}_{3}$ Merck, $\mathrm{Pb}(\mathrm{COO})_{2}$ Merck, standar glukosa Merck, akuades, kertas $\mathrm{pH}$, dan kertas saring Whatman No. 42. Alat-alat yang digunakan adalah neraca analitik Ohaus, kaca arloji, mortar dan alu, gelas ukur Pyrex, corong, labu ukur Pyrex, tabung reaksi Pyrex, pipet volumetrik Pyrex, oven Memmert B40, gelas piala Pyrex, spektrofotometer UV-Vis Optizen POP, blender Phillips.

\section{Metode}

Penelitian dilakukan dalam tiga tahap yaitu penanaman tetua dan klon mutan galur harapan tanaman talas Bogor di dua lokasi lahan, panen dan pengambilan sampel, serta penentuan kandungan klorofil dan kandungan karbohidrat.

\section{Penanaman Klon Mutan Galur Harapan Tanaman Talas Bogor}

Tetua dan klon mutan galur harapan tanaman talas Bogor ditanam di lahan yang berlokasi di Kecamatan Cijeruk dan Kecamatan Kemang. Masing-masing klon dibagi menjadi tiga 
kelompok dengan tiga kali ulangan. Tanah pada lahan tersebut digemburkan terlebih dahulu lalu dibuat bedeng-bedeng dengan lebar $80 \mathrm{~cm}$ dan tinggi $50 \mathrm{~cm}$. Masing-masing bedeng dibuat lubang dengan kedalaman $30 \mathrm{~cm}$. Bibit tetua dan klon mutan galur harapan ditanam pada masingmasing lubang dengan jarak antar tanaman 1 meter. Tetua dan klon mutan galur harapan diberi pupuk kandang sebanyak 200 gram dan furadan sebanyak 1 sendok makan. Jumlah anakan dan jumlah daun tetua dan klon mutan galur harapan dihitung tiap minggu setelah ditanam. Klon mutan galur harapan ditanam selama 36 minggu.

\section{Panen dan Pengambilan Sampel}

Tetua dan klon mutan galur harapan dipanen pada 36 Minggu Setelah Tanam (MST). Tanaman talas diangkat lalu dibersihkan dari sisa-sisa tanah dengan air mengalir hingga bersih. Umbi yang sudah dipotong dari batang tanaman ditimbang dan dicatat bobot basahnya dan disimpan untuk penentuan kandungan karbohidrat. Daun tanaman diambil untuk selanjutnya dilakukan penentuan kandungan klorofil.

\section{Penentuan Kandungan Klorofil (Yoshida, Forno, Cock, \& Gomez, 1976)}

Daun talas dipotong menjadi bagian-bagian kecil dan ditimbang sebanyak 2 gram, lalu dihaluskan dengan menggunakan mortar. Daun yang telah dihaluskan ditambahkan aseton 80\% secukupnya, dihomogenkan, dan disaring ke dalam labu ukur $100 \mathrm{~mL}$. Sampel diekstraksi hingga didapatkan larutan ekstraksi sebanyak $100 \mathrm{~mL}$. Larutan dipipet sebanyak $10 \mathrm{~mL}$, dimasukkan ke dalam labu ukur $25 \mathrm{~mL}$ dan ditera dengan aseton $80 \%$ hingga garis batas. Larutan tersebut diukur absorbansinya dengan menggunakan spektrofotometer UV-Vis pada panjang gelombang $645 \mathrm{~nm}$ dan $663 \mathrm{~nm}$.

Kadar klorofil ditentukan dengan menggunakan persamaan:

$$
\begin{aligned}
& \mathrm{Ca}=(12,7 \times \mathrm{D} 663-2,69 \times \mathrm{D} 645) \times \mathrm{fp} \\
& \mathrm{Cb}=(22,9 \times \mathrm{D} 645-4,68 \times \mathrm{D} 663) \times \mathrm{fp}
\end{aligned}
$$

Untuk menghitung kadar klorofil total menggunakan persamaan :

Total klorofil $(\mathrm{mg} / \mathrm{L})=\mathrm{Ca}+\mathrm{Cb}$
Keterangan :

D663 = Absorbansi pada panjang gelombang $663 \mathrm{~nm}$.

D645 = Absorbansi pada panjang gelombang $645 \mathrm{~nm}$.

$\mathrm{Ca}=$ Kadar klorofil a $(\mathrm{mg} / \mathrm{L})$

$\mathrm{Cb} \quad=$ Kadar klorofil $\mathrm{b}(\mathrm{mg} / \mathrm{L})$

$\mathrm{fp} \quad=$ Faktor pengenceran

12,$7 ; 4,68 ; 2,69$; dan 22,9 adalah koefisien absorbsi spesifik untuk klorofil a dan klorofil b pada panjang gelombang 663 dan $645 \mathrm{~nm}$.

\section{Penentuan Kandungan Karbohidrat (Andarwulan et al., 2011) Persiapan Sampel}

Umbi talas ditimbang sebanyak 20-30 gram, ditambahkan alkohol $80 \%$ dengan perbandingan 1:1 atau 1:2, kemudian dihancurkan dengan blender. Sampel dipindahkan ke dalam gelas piala, kemudian disaring dengan menggunakan kapas, dan filtrat yang dihasilkan dipindahkan ke dalam gelas piala. Sisa padatan pada kapas dibilas dengan alkohol $80 \%$ hingga seluruh gula larut dalam filtrat. $\mathrm{pH}$ sampel diukur dengan menggunakan kertas $\mathrm{pH}$. Apabila $\mathrm{pH}$ asam, maka ditambahkan $\mathrm{CaCO}_{3}$ sampai $\mathrm{pH} 8$ dan dipanaskan di penangas air pada suhu $100^{\circ} \mathrm{C}$ selama 30 menit. Setelah dingin, sampel disaring kembali dan ditambahkan $\mathrm{Pb}(\mathrm{COO})_{2}$ jenuh secara perlahan sampai larutan jernih. Setelah diperoleh filtrat yang jernih, volume larutan ditempatkan sampai volume tertentu dengan air, lalu dihomogenkan.

\section{Pembuatan Kurva Standar dan Penentuan Kandungan Karbohidrat \\ Larutan standar glukosa disiapkan dengan} konsentrasi $50 \mathrm{mg} / \mathrm{mL}$. Selanjutnya, dengan pengenceran dibuat deret standar $1,0 \mathrm{mg} / \mathrm{mL}, 1,5$ $\mathrm{mg} / \mathrm{mL}, 2,0 \mathrm{mg} / \mathrm{mL}, 3,0 \mathrm{mg} / \mathrm{mL}$, dan $5,0 \mathrm{mg} / \mathrm{mL}$. Lalu, setiap deret standar dipipet ke dalam tabung reaksi bertutup masing-masing sebanyak $1 \mathrm{~mL}$. Blanko dibuat dengan memipet $1 \mathrm{~mL}$ akuades ke tabung lainnya. Kemudian, ke dalam tabung masing-masing ditambahkan $5 \mathrm{~mL}$ pereaksi Anthrone dengan cepat dan tabung reaksi ditutup. Setelah didinginkan, larutan dipindahkan ke dalam kuvet dan diukur absorbansinya pada panjang gelombang $630 \mathrm{~nm}$ untuk memperoleh data kurva standar. Untuk sampel, dipipet sebanyak $1 \mathrm{~mL}$ 
sampel ke dalam tabung reaksi lalu dilanjutkan tahap yang sama dengan pembuatan standar.

\section{HASIL DAN PEMBAHASAN}

Hasil penelitian menunjukkan bahwa kandungan klorofil daun talas yang ditanam di Kecamatan Kemang lebih tinggi diandingkan dengan yang ditanam di Kecamatan Cijeruk (Gambar 1). Kandungan klorofil tertinggi di lokasi lahan Kecamatan Kemang adalah klon B1023, sedangkan di Kecamatan Cijeruk adalah klon B1511. Hal ini dapat disebabkan oleh faktor genetik dari masing-masing klon mutan. Selain itu, faktor lingkungan juga dapat mempengaruhi kandungan klorofil pada klon mutan. Menurut (Arman \& N. Armani, 2016), pembentukan klorofil dipengaruhi oleh beberapa faktor diantaranya faktor genetik, hara nitrogen, oksigen, cahaya, karbohidrat, besi, dan magnesium. Besarnya kandungan klorofil klon mutan yang ditanam di Kecamatan Kemang dapat dipengaruhi oleh kandungan hara tanah di lokasi penanaman. Berdasarkan analisis tanah yang dilakukan sebelumnya (Nurilmala, Yuliani, \& Aisyah, 2017) terhadap lahan penanaman di Kecamatan Cijeruk dan Kecamatan Kemang, kandungan unsur nitrogen dalam tanah di Kecamatan Cijeruk lebih rendah dibandingkan di Kecamatan Kemang. Hal ini dapat menjadi penghambat sintesis klorofil pada klon mutan karena unsur nitrogen berperan dalam sintesis klorofil pada tanaman sehingga kandungan klorofil klon mutan yang ditanam di Kecamatan Cijeruk lebih rendah. Serapan nitrogen yang besar pada tanaman akan menghasilkan kandungan klorofil yang besar sehingga proses metabolisme dapat meningkat, terutama pada proses fotosintesis (Waskito, Aini, \& Koesriharti, 2017)

Klorofil merupakan komponen penting dalam proses fotosintesis dan berkorelasi positif dengan laju fotosintesis. Pada tumbuhan, fotosintesis merupakan proses penting untuk mempertahankan pertumbuhan dan perkembangan tanaman yang dapat diamati pada jumlah anakan dan jumlah daun. Gambar 2 menunjukkan bahwa kandungan klorofil yang tinggi tidak memberikan pengaruh terhadap jumlah anakan dan daun di lokasi
Kecamatan Kemang dan Cijeruk. Hal ini diduga karena posisi masing-masing tanaman terhadap penyinaran cahaya matahari pada masing-masing talas berbeda walaupun berada pada lokasi lahan yang sama. Sejalan dengan penelitian (Lawendatu, Pontoh, \& Kamu, 2019) bahwa kandungan klorofil pada tiap tanaman berbeda-beda sesuai dengan posisi daun tersebut, misalnya pada daun yang lebih banyak mendapat cahaya matahari mempunyai klorofil yang lebih tinggi jika dibandingkan dengan daun yang kurang mendapat cahaya matahari. Namun bila intensitas cahaya matahari terlalu tinggi, maka akan mengakibatkan suhu menjadi tinggi sehingga hal ini menyebabkan terjadinya kerusakan klorofil dan kandungan klorofil menurun yang berpengaruh terhadap aktivitas enzim klorofilase dan enzim lipoksidase. Selain itu, hasil penelitian ini diduga berkaitan dengan kandungan unsur nitrogen yang berperan penting dalam pertumbuhan vegetatif tanaman seperti pertumbuhan daun dan anakan serta pembentukan klorofil (Elisabeth, Santosa, \& Herlina, 2013).

Klon B1511 di Kecamatan Cijeruk memiliki kandungan klorofil total paling tinggi dibandingkan dengan klon lainnya tetapi memiliki jumlah anakan dan jumlah daun paling sedikit yaitu 5 anakan dan 11 daun. Klon B1023 dengan kandungan klorofil total paling kecil memiliki jumlah anakan dan jumlah daun yang cukup banyak yaitu 19 anakan dan 14 daun. Jumlah anakan dan jumlah daun paling banyak dimiliki oleh klon B521 yaitu 23 anakan dan 15 daun, tetapi kandungan klorofilnya kecil. Hal ini dapat disebabkan karena perbedaan kondisi lahan penanaman di Kecamatan Cijeruk dan Kecamatan Kemang. Kandungan unsur nitrogen di lahan Kecamatan Cijeruk lebih rendah dibandingkan dengan lahan Kecamatan Kemang (Nurilmala et al., 2017), sehingga dapat menyebabkan pertumbuhan klon mutan galur harapan di Kecamatan Cijeruk terhambat. Menurut (Buntoro, Rogomulyo, \& Trisnowati, 2014) faktor internal (genetik) dan faktor eksternal (lingkungan) mempengaruhi pertumbuhan dan perkembangan tanaman. Pertumbuhan dan perkembangan tidak dapat berjalan dengan baik apabila salah satu faktor atau kedua faktor internal dan eksternal tersebut tidak saling mendukung. 


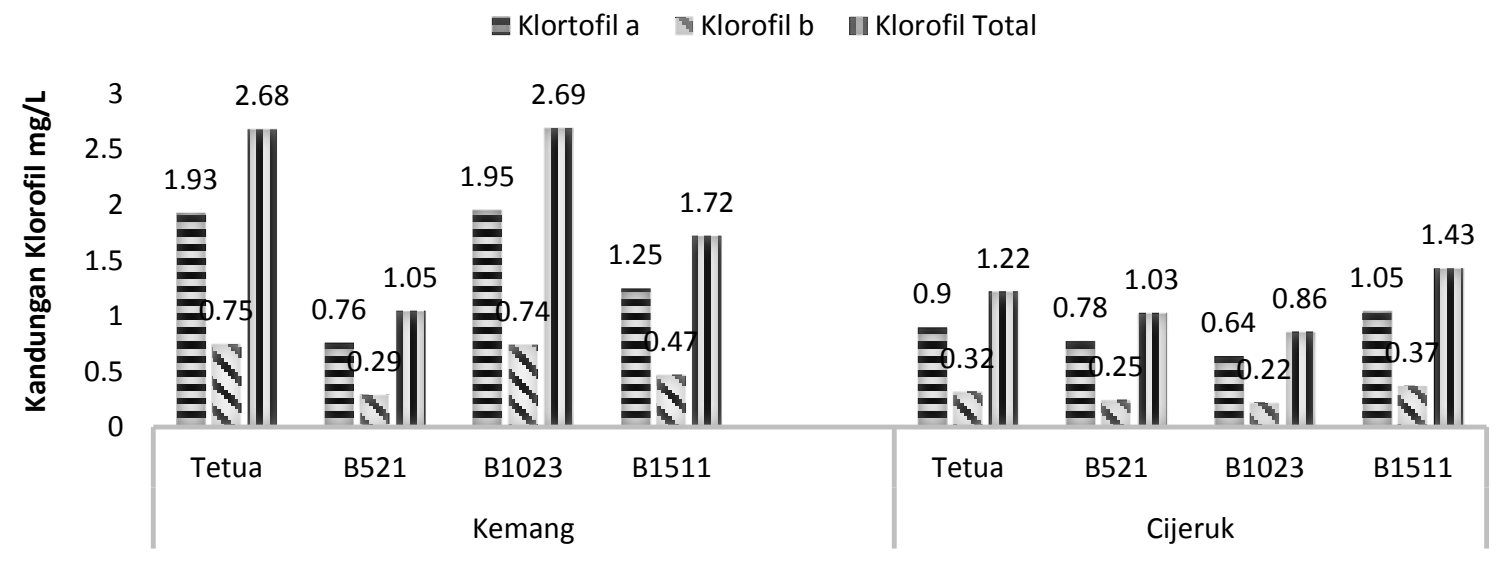

Lokasi Lahan

Gambar 1. Kandungan Klorofil pada Daun Tetua dan Klon Mutan Galur Harapan Talas Bogor (Colocasia esculenta (L.) Schott) di Kecamatan Kemang dan Kecamatan Cijeruk Kabupaten Bogor.

田Jumlah Anakan 圆 Jumlah Daun

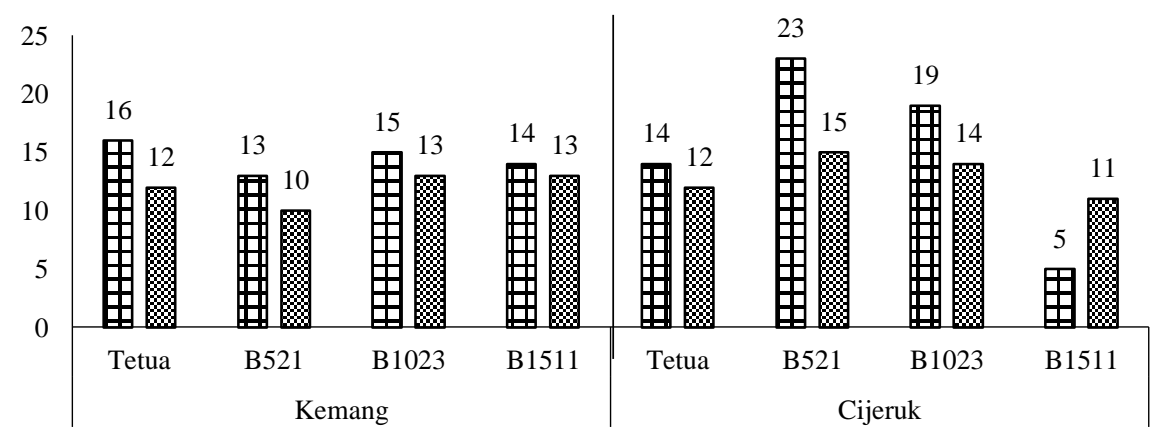

Gambar 2. Jumlah Anakan dan Jumlah Daun Tetua dan Klon Mutan Galur Harapan Tanaman Talas Bogor (Colocasia esculenta (L.) Schott) di Kecamatan Kemang dan Kecamatan Cijeruk.

Klon mutan galur harapan B1023 dan tetua yang ditanam di Kecamatan Kemang dengan kandungan klorofil total tinggi memiliki bobot basah umbi yang kecil (Gambar 3). Bobot basah umbi tetua dan klon B1023 yaitu 496,67 g dan 400 g. Klon B521 dan klon B1511 memiliki kandungan klorofil yang rendah, tetapi memiliki bobot basah umbi yang besar yaitu 606,67 $\mathrm{g}$ dan 546,67 g. Klon B521 dan klon B1023 yang ditanam di Kecamatan Cijeruk memiliki kandungan klorofil rendah dari klon lainnya, tetapi memiliki bobot basah umbi yang besar yaitu $688,33 \mathrm{~g}$ dan $470 \mathrm{~g}$. Tetua dan klon B1511 yang kandungan klorofilnya tinggi memiliki bobot basah umbi yang lebih kecil yaitu 176,67 g dan 185 g. Klon-klon mutan galur harapan dengan kandungan klorofil total tinggi memiliki bobot umbi yang kecil, dan sebaliknya. Menurut (Irwan, Wicaksono, \& Yulianto, 2016) proses fotosintesis menghasilkan fotosintat yang selanjutnya ditranslokasikan ke bagian-bagian tanaman lainnya dan digunakan baik untuk pertumbuhan tanaman maupun sebagai cadangan makanan. Selanjutnya (Winata, Karno, \& Sutarno, 2012) menyatakan bahwa pertumbuhan tanaman dibagi menjadi dua tahap, yaitu pertumbuhan vegetatif yaitu pertumbuhan daun dan anakan serta pertumbuhan generatif yaitu pembentukan umbi. Proses fotosintesis yang berjalan maksimal akan memicu pertumbuhan vegetatif dan generatif yang baik. Pertumbuhan vegetatif yang terlalu dominan dapat menghambat distribusi fotosintat yang seharusnya disalurkan kepada umbi (Buntoro et al., 2014). 


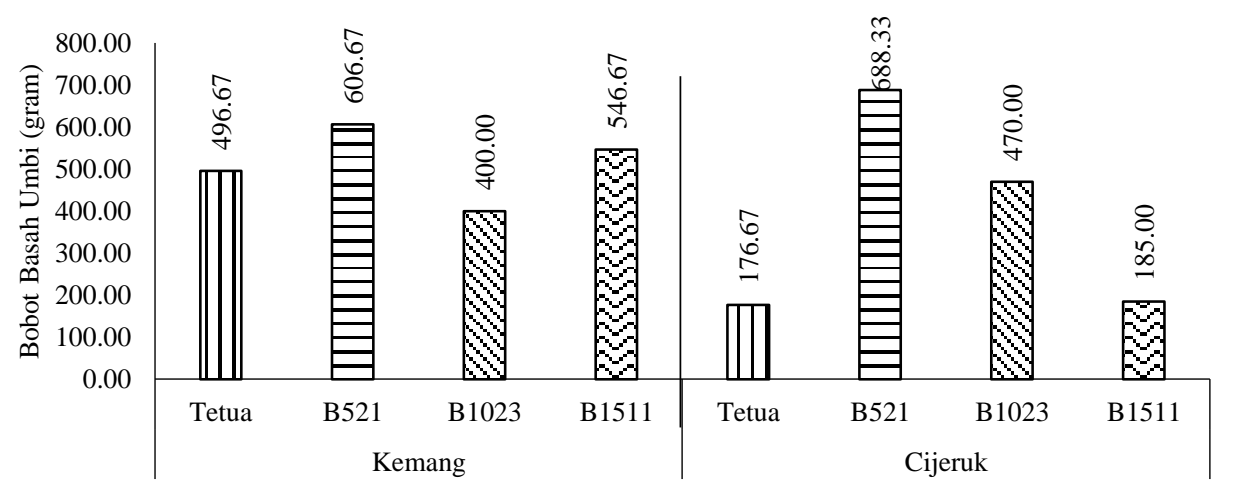

Gambar 3. Bobot Basah Umbi Tetua dan Klon Mutan Galur Harapan Tanaman Talas Bogor (Colocasia esculenta (L.) Schott) di Kecamatan Kemang dan Kecamatan Cijeruk.

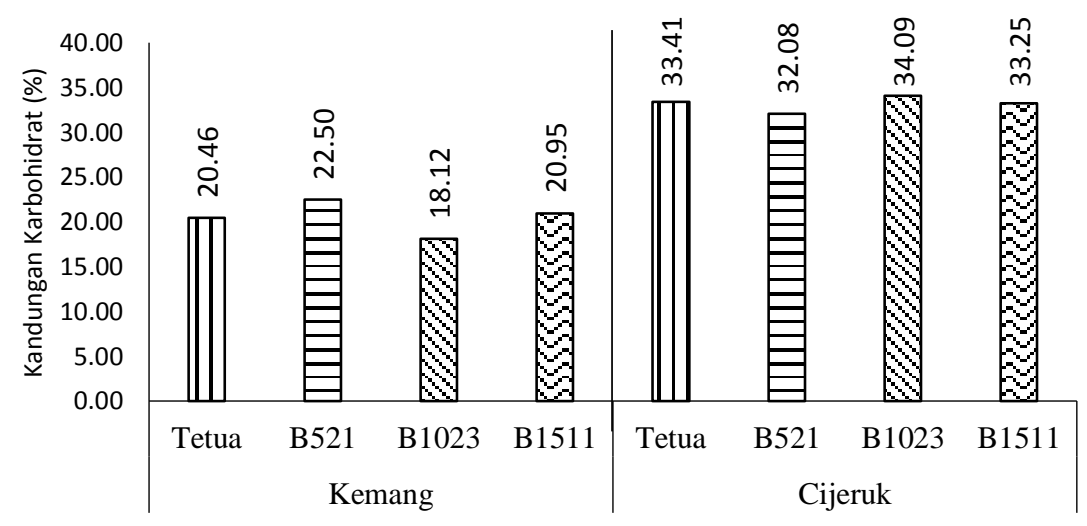

Gambar 4. Kandungan Karbohidrat Tetua dan Klon Mutan Galur Harapan umbi Talas Bogor (Colocasia esculenta (L.) Schott) di Kecamatsan Kemang dan Kecamatan Cijeruk.

Umbi klon B521 dan klon B1511 hasil panen di Kecamatan Kemang yang berbobot basah umbi besar memiliki kandungan karbohidrat yang tinggi yaitu $22,50 \%$ dan 20,95\%, sedangkan umbi tetua dan klon B1023 yang berbobot kecil memiliki kandungan karbohidrat yang lebih rendah yaitu 20,46\% dan 18,12\% (Gambar 4). Begitu pula dengan umbi klon B1023 dan klon B1511 yang ditanam di Kecamatan Cijeruk memiliki bobot basah umbi yang besar dan kandungan karbohidratnya tinggi yaitu sebesar 34,09\% dan $33,25 \%$.

Kandungan karbohidrat klon mutan galur harapan berbanding terbalik dengan kandungan klorofil. Klon-klon mutan galur harapan dengan kandungan klorofil tinggi memiliki kandungan karbohidrat rendah dan sebaliknya. Fotosintat ditranslokasikan ke bagian-bagian tanaman lain berupa monosakarida seperti glukosa dan fruktosa yang merupakan bentuk sederhana dari karobhidrat (Pahlevi, Guritno, \& Suminarti, 2016). Pembentukan umbi pada fase generatif tanaman sangat memerlukan karbohidrat. Kandungan karbohidrat yang rendah merupakan gejala terjadinya persaingan translokasi fotosintat. Jika fotosintat lebih banyak disalurkan untuk membentuk daun dan anakan, maka pertumbuhan vegetatif tanaman meningkat sementara bobot basah umbi serta kandungan karbohidratnya menurun (Lubis \& Suwarto, 2018).

Pada penelitian ini, kandungan klorofil berbanding lurus dengan jumlah daun dan jumlah anakan tetapi berbanding terbalik dengan bobot basah umbi dan kandungan karbohidrat. Kandungan klorofil tidak mempengaruhi jumlah daun dan jumlah anakan tetapi berbanding terbalik dengan bobot basah umbi dan kandungan karbohidrat. Intensitas cahaya merupakan salah 
satu faktor yang mempengaruhi pertumbuhan dan perkembangan tanaman. Energi cahaya diterima oleh tanaman dengan penyerapan langsung oleh molekul pigmen seperti klorofil (Zakiyah, Manurung, \& Wulandari, 2018). Sedangkan produksi tanaman dipengaruhi oleh kondisi tanah dan iklim yang berkaitan erat dengan faktor lingkungan seperti zat hara, air, dan suhu (Lestari, Solichatun, \& Sugiyarto, 2008). Hal ini menunjukkan bahwa translokasi fotosintat lebih banyak disalurkan ke pertumbuhan vegetatif daripada pertumbuhan generatif klon mutan galur harapan. Hal ini dapat disebabkan oleh anakananakan yang tumbuh tidak dicabut. Menurut (Buntoro et al., 2014) banyaknya anakan yang tumbuh dapat menghambat distribusi fotosintat yang seharusnya disalurkan pada umbi.

\section{KESIMPULAN}

Klon mutan galur harapan B1023 yang ditanam di Kecamatan Kemang memiliki kandungan klorofil lebih tinggi dari tetua. Sedangkan pada klon mutan galur harapan B1511 yang ditanam di Kecamatan Cijeruk memiliki kandungan klorofil lebih tinggi dari tetua. Kandungan klorofil tinggi berbanding terbalik dengan bobot basah umbi dan kandungan karbohidrat, tetapi tidak memberikan pengaruh terhadap jumlah daun dan anakan. Kandungan klorofil klon mutan galur harapan yang ditanam di Kecamatan Kemang lebih tinggi dibandingkan dengan kandungan klorofil klon mutan harapan yang ditanam di Kecamatan Cijeruk.

\section{DAFTAR PUSTAKA}

Andarwulan, N., Kusnandar, F., \& Herawati, D. (2011). Analisis Pangan. Dian Rakyat Jakarta.

Arman, Z., \& N. Armani. (2016). Respons Fisiologi, Pertumbuhan, Produksi Dan Serapan P Bawang Merah (Allium Ascalonicum L.) Terhadap Pemberian Trichokompos Tandan Kosong Kelapa Sawit (Tkks) Terformulasi Dan Pupuk P Di Lahan Gambut. Jurnal Agroteknologi, 6(2), 15. https://doi.org/10.24014/ja.v6i2.2236
Bermawie, N., Meilawati, N. L. W., S. Purwiyant, \& Melati. (2015). Pengaruh Iradiasi Sinar Gamma Terhadap Jahe Putih Kecil (Zingiber officinale var. amarum). Jurnal Littri, 21(2), $47-56$.

Buntoro, B. H., Rogomulyo, R., \& Trisnowati, S. (2014). Pengaruh Takaran Pupuk Kandang dan Intensitas Cahaya Terhadap Pertumbuhan dan Hasil Temu Putih (Curcuma zedoaria L.). Vegetalika, 3(4), 2939.

Elisabeth, D. W., Santosa, M., \& Herlina, N. (2013). The effect of various compositions of organic matter on growth and yield of shallot (Allium ascalonicum L .). Jurnal Produksi Tanaman, 1(3), 21-29.

FAO/IAEA DIVISIONOF ATOMIC ENERGY IN FOOD AND AGRICULTURE. (1977). Manual on mutation breeding 2 nd edition. In International Atomic Energy Vienna (Vol. 119).

Irwan, A. W., Wicaksono, \& Yulianto, F. (2016). Pengaruh pupuk pelengkap cair dan sistem olah tanah terhadap pertumbuhan dan hasil kacang tanah (Arachis hypogaea L.) kultivar nkancil pada inceptisols Jatinangor. Kultivasi, 15(3), 217-225. https://doi.org/10.24198/kultivasi.v15i3.1176 7

Lawendatu, O. P., Pontoh, J., \& Kamu, V. S. (2019). Analisis Kandungan Klorofil Pada Berbagai Posisi Daun Dan Anak Daun Aren (Arrenga pinnata). Chemistry Progress, 12(2), 67-72. https://doi.org/10.35799/cp.12.2.2019.26414

Lestari, G. W., Solichatun, \& Sugiyarto. (2008). Pertumbuhan, Kandungan Klorofil, dan Laju Respirasi Tanaman Garut (Maranta arundinacea) setelah Pemberian Asam Giberelat (GA3). Bioteknologi, 5(1), 1-9. https://doi.org/10.13057/biotek/c050101

Li, R., Guo, P., Baum, M., Grando, S., \& Ceccarelli, S. (2006). Evaluation of Chlorophyll Content and Fluorescence Parameters as Indicators. Agricultural Sciences in China, 5(October), 751-757.

Lubis, L. W. K., \& Suwarto. (2018). Pengaruh 
Jarak Tanam dan Dosis Pupuk Kalium Terhadap Pertumbuhan dan Produksi Talas Belitung (Xanthosoma sagittifolium (L.)). Buletin Agrohorti, 6(1), 87-98.

Mugiono. (1996). Pengaruh Iradiasi Sinar Gamma Terhadap Keragaman Ketahan Penyakit Blas Pada Padi Gogo.

Nurilmala, F., Hutagaol, R. P., Widhyastini, I. G. A. M., Widyastuti, U., \& Suharsono. (2017). Somaclonal variation induction of bogor taro (Colocasia esculenta) by gamma irradiation. Biodiversitas, 18(1), 28-33. https://doi.org/10.13057/biodiv/d180105

Nurilmala, F., \& Mardiana, D. (2019). Nutrients and Anti-nutrients Content Analysis of Bogor Taro Mutant Clone (Colocasia esculenta). IOP Conference Series: Earth and Environmental Science, $334(1)$. https://doi.org/10.1088/17551315/334/1/012070

Nurilmala, F., N. Yuliani, \& Aisyah. (2017). Laporan Penelitian Terapan KemenristekDIKTI: Uji Multilokasi Klon Mutan Galur Harapan Tanaman Talas Bogor (Colocasia esculenta (L.) Schott).

Pahlevi, R. W., Guritno, B., \& Suminarti, E. N. (2016). Pengaruh Kombinasi Proporsi Pemupukan Nitrogen Dan Kalium Pada Pertumbuhan, Hasil Dan Kualitas Tanaman Ubi Jalar ( Ipomea The Effect Of Proportion Combination Nitrogen And Potassium Fertilization On Growth, Yield And Quality Of Sweet Potato ( Ipomea Bat). Jurnal Produksi Tanaman, 4(1), 16-22.

Shu, Q. Y., Forster, B. P., \& H. Nakagawa. (2012). Plant mutation breeding and biotechnology. In Plant Mutation Breeding and Biotechnology. https://doi.org/10.1079/9781780640853.0000

Suminarti, N. E. (2010). Pengaruh pemupukan N dan $\mathrm{K}$ pada pertumbuhan dan hasil tanaman talas yang ditanam di lahan kering. Akta Agrosia, 13(1), 1-7.

Waskito, K., Aini, N., \& Koesriharti. (2017). Effect of Plant Media Composition and Nitrogen Fertilizer on Growth and Yield of Eggplant Plants (Solanum melongena L.). Produksi Tanaman, 5(10), 1586-1593. Retrieved from http://protan.studentjournal.ub.ac.id/index.ph $\mathrm{p} / \operatorname{protan} /$ article/view/545

Winata, N. A. S. H., Karno, \& Sutarno. (2012). Pertumbuhan Dan Produksi Hijauan Gamal ( Gliricidia Sepium ) Dengan Berbagai Dosis Pupuk Organik Cair N. A. S. H. Winata, Karno dan Sutarno Fakultas Peternakan dan Pertanian Universitas Diponegoro Semarang. Animal Agriculture, 1(1), 797-807.

Wulansari, A., Marthin, A. F., Ermayanti, \& Muji, T. (2016). Induksi Tanaman Poliploid Talas ( Colocasia esculenta L .) dengan Perlakuan Orizalin secara In Vitro. Jurnal Biologi Indonesia, 12(2), 297-305.

Yoshida, S., Forno, D. A., Cock, J. H., \& Gomez, K. A. (1976). Laboratory Manual for Physiological Studies of Rice. In The International Rice Research Institute.

Zakiyah, M., Manurung, F. T., \& Wulandari, R. C. (2018). Kandungan Klorofil Daun Pada Empat Jenis Pohon Di Arboretum Sylva Indonesia Pc. Universitas Tanjungpura (Leaf Chlorophyll Content In Four Tree Species at Arboretum Sylva Indonesia PC. Universitas Tanjungpura). Jurnal Hutan Lestari, 6(1), $48-55$. 